\title{
Astrology as Heresy in Contemporary Belief
}

\author{
Garry Phillipson \\ Sophia Centre for the Study of Cosmology in Culture \\ Faculty of Humanities and the Performing Arts \\ University of Wales Trinity Saint David
}

\begin{abstract}
Astrology has been characterised as a heresy by many Christian thinkers, from the time of the early Church Fathers to the present day. In contemporary discourse, astrology is often treated as if it were a heresy against science. I provide examples of astrologers being treated as heretics in the name of science, and an alternative conception of astrology as a form of divination, not dependent on scientific substantiation. I argue that the 'astrology' often criticised in the name of science may be defined as much by scientism's need for a construction to define itself against, as by the actual views of horoscopic astrologers. The emerging picture is that criticisms of astrology are typically based on a mixture of legitimate objections and scientistic belief. I conclude that scientism's unspoken aspiration to orthodoxy emerges through the parallels between its approach to astrology and that of the Church. ${ }^{1}$
\end{abstract}

\section{Introduction}

My central argument in this paper is that criticism of astrology often treats it, not as simply wrong or mistaken, but as a heresy against science. Heresy implies orthodoxy - here I follow Jeffrey Burton Russell's description of the relationship as symbiotic, with orthodoxy and heresy each defining the other to a certain degree (Russell 1992: 4). To the extent that astrology is treated as heretical under the authority of science, therefore, the assertion by Richard N. Williams that 'scientism is the new orthodoxy' is substantiated (Williams and Robinson 2015: 2). Williams characterises scientism as an 'over-reliance on and overconfidence in science as the source of knowledge regarding all aspects of human life and, ultimately, all human problems' (Williams and Robinson: $2-3$ ). Although my analysis focuses on astrology, it could easily be applied to a number of other 'fringe' practices, and it has ramifications for the study of belief in society as a whole.

In order to develop the meaning of 'heresy' I will draw parallels with the historical treatment of astrology as heresy by the Christian Church. ${ }^{2}$ This does not imply the persistence through centuries of a monolithic organisation in which opinions were fully consonant; it is an integral part of my argument that the ongoing dialectic between orthodoxy and heresy shows there always to have been something notional and aspirational about the term 'the Church' and its orthodoxy. Ultimately the referents of these terms are found in the aspirations of individuals, notwithstanding the fact that those aspirations coalesce, more or less, as organisations that exercise power in the world. The parallel here between the Church and scientism is central to this paper: the pursuit of a universal orthodoxy based on science comprises many nuances and divergences of opinion, but the power of the aspiration

\footnotetext{
${ }^{1}$ My thanks to Patrick Curry and Kirk Little for their input on this and other musings over the years; and to Darrelyn Gunzburg for her help in clarifying and finalising this paper.

${ }^{2}$ For the era in which the terms could be ambiguous, 'Christian Church' and 'the Church' will refer specifically to the Roman Catholic Church. For the relationship between the Church and astrology see, for example, Campion 2012A: 161 - 172; Hegedus 2007.
} 
manifests as organisations and loose associations of individuals who exercise power in the contemporary world. That exercise of power, I will argue, is seen in the condemnation of divergent views as if they are heresies against science.

This paper will contribute to the study of belief, most particularly concerning astrology and scientism, but also to some degree regarding theology. In this way, it builds on Michael T. Cooper's assertion that 'Both disciplines [theology and astrology] have been marginalized by the academy... [and] there has been an intriguing relationship between the two' (Cooper 2007: 190). One facet of the 'intriguing relationship' is that both are sometimes tarred with the same brush in the name of science, as when A. C. Grayling asserted: 'Religion is exactly the same thing [as astrology]: it is the pre-scientific, rudimentary metaphysics of our forefathers, which (mainly through the natural gullibility of proselytised children, and tragically for the world) survives into the age in which I can send this letter by electronic means' (Grayling 2006).

\section{Precedents}

Precedents for the premise that science has usurped religion's tendency to cry heresy can be found in Steve Fuller's argument that 'science has inherited and rationalized Christianity's propensity to heresy’ (Fuller 2007: 19). In similar vein, Michael Polanyi suggested that 'modern scientism fetters thought as cruelly as ever the churches had done', and Paul Feyerabend suggested that 'science has now become as oppressive as the ideologies it once had to fight' (Polanyi 1962: 265; Feyerabend 1975: 5). A similar trend of thought is reflected by the contemporary currency of the term 'secular fundamentalism' for forms of belief that reify science (for example, Conkle 1995: 348 - 9).

Precedents for astrology's characterisation as heresy can be found in Franz Cumont's history of astrology when, apparently without irony, he remarks: 'Under the sway of reason the eighteenth and nineteenth centuries condemned this heresy in the name of scientific orthodoxy' (Cumont 1912: xvi-xvii). Patrick Curry argued that 'for most scientists today... contemporary astrology is a reminder... of the failure of their collective mission of universal enlightenment, i.e. disenchantment. In other words... astrology is scientific heresy' [original emphasis](Willis and Curry 2004: 94). Arthur Versluis's book The New Inquisitions develops ideas of heresy as a secular phenomenon with some coverage of astrology, particularly a critique of Theodor Adorno’s attack on astrology (Versluis 2006: 95 - 104; Adorno 1994:46171.) Olav Hammer and Kocku von Stuckrad, writing of 'esotericists' (Hammer \& von Stuckrad 2007: vi n.1.) - a group including astrologers - noted: 'The fact that Christian polemics is no longer as shrill as it once used to be, by no means implies that esotericists can ply their trade in peace. The role of prime critic has been taken over by interest groups presenting a perspective based on the natural sciences' (Hammer \& von Stuckrad 2007: xix).

\section{Heresy and its Relationship to Astrology: Brief Definition and History}

The current usage of 'heresy' in the sense of deviance from an orthodox religious path emerged, under the influence of Christianity, between the end of the first century CE and the middle of the following century (Royalty 2013:3). As Robert M. Royalty notes, before this, the Greek word hairesis and its cognates carried no pejorative connotation and related to the word's etymological root, 'choice'. When 'heresy' is defined, the Catholic Catechism 2089 is often cited (Chapman 1999: 454): 'Heresy is the obstinate post-baptismal denial of some truth which must be believed with divine and catholic faith, or it is likewise an obstinate doubt concerning the same' (See for example Doe 2013: 210, Mühlenberg 2001: 529).

The New Testament contains astrological themes and references that may suggest a sympathetic attitude amongst some figures in the very early Church (Campion 2012: 165 8). This notwithstanding, the early Christian text the Didache, dated by Robert Aldrige to 
c.70-125 CE (Aldrige 1999:1, 2), counselled against the use of astrology. Didache 3.4 states: 'My child, do not practice divination since this leads to idolatry; nor use incantations or astrology...' (Ehrman 2003: 421). In c. 180 CE, St. Irenaeus (c. 130 - 202 CE) inveighed against astrology as part of his lengthy characterisation of heresy:

Marcus, maker of idols, observer of portents,

Skilled in astrology and in all arts of magic,

Whereby you confirm your erroneous doctrines.

Showing wonders to whomever you lead into error,

Showing the works of the apostate Power,

Marvels which Satan, your father, teaches you always... (Irenaeus, Against the

Heresies in Unger \& Dillon 1992: 68 [1.15.6])

Irenaeus enjoyed considerable influence over the subsequent evolution of the Church's approach to heresy, with the passage above being cited by many subsequent heresiologists including Hippolytus of Rome in the third century CE and Epiphanius of Salamis in the fourth century CE (Royalty 2013: 173; Hegedus 2007: 146). Astrology was thus tied up in the Church's characterisation of heresy from the first, serving to define the term and in turn being defined by it.

There was however a range of views in the early Church. Irenaeus's contemporary Tertullian (c. 155 - 240 CE) acknowledged that astrology was responsible for the magi being guided to Jesus's birth, but stated that its use was henceforth not permitted. He based this on an ingenious interpretation of Matthew 2.12, wherein the magi were warned in a dream not to return from Bethlehem by the way they had come. For Tertullian this did not refer to their outward itinerary, but to their use of astrology (Tertullian, On Idolatory in Waszink, van Winden \& der Nat 1987: 37 [9.4 - 5]; Hegedus 2007: 308-9). The gospel's message in this analysis was that the use of astrology had been both allowable and efficacious up to the birth of Jesus, but not thereafter. Origen (c. 185 - $255 \mathrm{CE}$ ) raised the question of why astrology worked sometimes and concluded, 'The cause is clear to us who have learned the secret, viz. that being free to exercise our faculties of reason we sometimes yield to concupiscence and suffer defeat, sometimes resolve to check it, and succeed' (Origen, Philocalia in Lewis 1911:197 [23.22]). This is a similar position to that taken by Thomas Aquinas nearly a millennium later, as I will discuss below. In Origen's view astrology dealt with signs rather than causal factors that would compel action; he characterised it as a form of divination comparable to seeing messages in the flight of birds, or from examining animal entrails (Origen, Philocalia in Lewis 1911: 189 - 90 [23.16]; Hegedus 2007: 331). For him, astrology was a viable and valid study in principle but its use was beyond the scope of humanity, suited only to angels (Origen in Lewis 1911: 193 - 4 [23.20]). On this and many other points Origen afforded more respect to a Neoplatonic world-view than did many of his influential successors, and he and his teachings were finally condemned in 400 by Pope Theophilus of Alexandria (fl. 384 - 412) (Referred to in a Letter of Jerome, in Schaff \& Wallace 2007: 184 [Letter XC]; Hegedus 2007: 147).

The prevalent attitude of the Church thereafter was that astrology belonged more to the Devil than the angels, with Theophilus's contemporary St. Augustine setting in place the enduring equation of astrology with heresy: 'To whom then must we make answer first - to the heretics or to the astrologers? For both come of the serpent, and desire to corrupt the Church's virginity of heart, which she holds in undefiled faith.' (Augustine, Lectures or Tractates On The Gospel of John 8.8 in Dods 1873:121). Astrology, characterised as a form of divination, continues to be proscribed in the most recent recension of the Catechism: 
2116 All forms of divination are to be rejected: recourse to Satan or demons, conjuring up the dead or other practices falsely supposed to 'unveil' the future. Consulting horoscopes, astrology, palm reading, interpretation of omens and lots, the phenomena of clairvoyance, and recourse to mediums all conceal a desire for power over time, history, and, in the last analysis, other human beings, as well as a wish to conciliate hidden powers. They contradict the honour, respect, and loving fear that we owe to God alone (Chapman 1999: 460).

This notwithstanding, an accommodation between astrology and the Church is still sometimes mooted. The Catholic priest Fr. Laurence L. Cassidy (1929 - 2006), commenting specifically on the above passage from the Catechism, argued that it permitted 'a rational astrology, a logos of the astra', albeit 'any doctrine of astrology that so identifies body with spirit that the two become totally subject to the efficient causality of celestial bodies is incompatible with Christian teaching' (Cassidy 1994: 12; 4). Cassidy traced his position back to Aquinas's analysis, which I will discuss later in this paper in the context of a comprehensive analysis of heresy.

\section{Kurtz's Analysis of Heresy}

Lester R. Kurtz (1983: 1086) proposed a sociological 'anatomy of heresy' comprising Five characteristics, and this provides a useful structure with which to discern the innate character of heresy at a remove from its historical manifestations. Five numbered sections follow, in which I deploy Kurtz's five characteristics to evaluate and show what it means to say that astrology is heresy, with reference both to the Church and to secular fundamentalism.

\section{The Deviant Insider}

Kurtz's first characteristic of heresy is that the heretic is 'a deviant insider' someone 'close enough to be threatening but distant enough to be considered in error' (Kurtz 1983: 1087). In the early Church this position can be seen particularly in the thought of Irenaeus, who shifted the focus of the institution's nascent heresiology from non-believers, to those who might consider themselves to follow the teachings of Christ, but were deemed to have wrong ideas about what that entailed (Kim 2015: 57). One needed to have known the tenets of the Church and have rejected them in order to be a heretic; 'Not every error is a heresy', as Augustine put it (Augustine, Arianism and Other Heresies Preface: 7 in Teske 1995: 33). The concept of deviant insiderhood is precisely what is conveyed when astrology is defined, as it often is by those antagonistic towards it, as a 'pseudoscience': in this view it should be a science, but falls short. The term 'pseudoscience' has gained wide currency since Karl Popper coined it in 1953, using astrology as a paradigmatic example (Popper 1969: 334). ${ }^{3}$

The distinction between blameless error and heresy came to be codified by the Church in the distinction between, respectively, 'formal heresy' and 'material heresy' (Cross \& Livingstone 1997: 758). A parallel distinction - between those who cannot be expected to know the truth, and those who can - is found in some criticisms of astrologers. Thus for instance in a newspaper article about astrology, Richard Dawkins $(1995: 17,18)$ suggested that 'some [people] are foolish enough to believe anything', and again that 'There are some stupid people out there, and they should be pitied not exploited'. On the other hand, he wondered 'whether the astrologers themselves believe in it' and suggested that a well-known newspaper astrologer 'may understand exactly what he is doing' (Dawkins 1995: 17). He

\footnotetext{
${ }^{3}$ The pages referred to were originally delivered as a lecture in 1953. Popper hyphenated 'pseudo-science' but subsequent usage frequently makes it a compound word.
} 
concluded by wondering 'Why, actually, are professional astrologers not jailed for fraud?' (Dawkins 1995: 18). In their critique, Bok and Jerome (1975: 10) assumed the same dichotomy between gullible innocents and guilty frauds, suggesting that the appeal of astrology lies in 'the comfort of having guidance in making decisions', whilst also attacking 'the pretentious claims of astrological charlatans'.

It seems often to be the case that the criticisms made of people interested in astrology, either as practitioners or as consumers, are not based on substantial acquaintance with the people concerned, and that judgements such as those just described are arrived at by inference; if astrologers are scientific 'insiders', it follows that they must be frauds. To redress the balance somewhat, three critics of astrology who have spent time with astrologers - Geoffrey Dean, Arthur Mather, and Rudolf Smit - reported that, in their experience, 'Astrologers were generally nice people, they seemed intelligent and well-educated, they spoke from the heart, and they based everything on practical experience' (Phillipson 2000: 125). This was despite their eventual conclusion that there is little or no scientific evidence to support astrology.

\section{The Problem of Authority}

Kurtz's second characteristic of heresy is that 'The problem of heresy... is essentially a problem of authority' wherein 'Authorities frequently defend, sometimes at high personal cost, what they perceive to be a genuine threat to what is considered sacred' (Kurtz 1983: 1088, 1089). Taking as an example the late nineteenth and early twentieth century modernist movement which was characterised as heretical by Catholicism, Kurtz remarked that 'What is puzzling at first glance is why there was so much concern on the part of a powerful institution over the work of a few somewhat isolated scholars and their sympathizers' (Kurtz 1983: 1095). Campion (2012B: 4) has suggested that the response to astrology in the UK is similarly disproportionate: 'One may ask why, if it is drivel, it arouses such anger, and why one part of British media regulation regards it as so dangerous'.

For Kurtz (1983: 1094) the reason that modernism was seen as heretical by Catholicism was that it threatened to subvert the authority of the Church. This fits with Fuller's characterisation of heresy as a denial of the authority of those regarded by some as experts, which results in a battle between conflicting knowledge claims (Fuller 2007: 26). An example of science's authority being asserted can be seen in Objections to Astrology, an article and subsequent book in which Bart Bok, Lawrence Jerome, and Paul Kurtz (1975: 10) presented the signatures of the '192 leading scientists, including 19 Nobel Prize winners' of its subtitle to affirm the statement that 'those individuals who continue to have faith in astrology do so in spite of the fact that there is no verified scientific basis for their beliefs, and indeed that there is strong evidence to the contrary'. ${ }^{4}$

The characterisation of this and similar critiques as arising from a 'problem of authority' is substantiated by the motivation professed by many critics of astrology. Thus for example Bok stated, 'During the past ten years, we have witnessed an alarming increase in the spread of astrology... most of our daily newspapers regularly carry columns about it and... some of our universities and junior colleges actually offer astrology courses' [Bok, Jerome, Paul Kurtz 1975: 21]. In similar vein, twenty years later Richard Dawkins explained his critique of astrology as being instigated by the appearance of astrological features in the

\footnotetext{
${ }^{4}$ The reader's attention is drawn to the appearance here, and subsequently, of a second Kurtz: Paul Kurtz was a philosopher and critic of astrology; the already cited Lester R. Kurtz is, as noted, a sociologist. I will distinguish between the two by giving Paul Kurtz's full name on each appearance, whilst 'Kurtz' simpliciter denotes Lester R. Kurtz.
} 
Independent on Sunday, Sunday Times, and Guardian newspapers (Dawkins 1995: 17). The popularity of astrology thus evokes a 'problem of authority' because it is seen as leading people away from 'true science', as encapsulated in a statement from the psychologist Gordon W. Allport that was quoted by Bok: 'It is unfortunate that in the minds of many people astrology is confused with true science. The result of this confusion is to prevent these people from developing truly scientific habits of thought...' (Bok, Jerome, Paul Kurtz 1975: 33).

The involvement of authority-issues in Objections to Astrology was raised as a problem by Carl Sagan (1976:2) who reported that he felt unable to endorse the statement, not out of any sympathy for astrology, but 'because I felt and still feel that the tone of the statement is authoritarian'. Paul Feyerabend (1978: 19-24) also criticised the authoritarian tone of the statement, comparing it to a guidebook used during the Inquisition, the Malleus Maleficarum. The issue of authority, discussed as a principle in this section, will be developed in the following section where its social application is the focus.

\section{Social Control}

'Through the labeling and suppression of heresy, institutional elites can rally support for their positions through battle with a common enemy' (Kurtz 1983: 1089). Kurtz's third characteristic of heresy focuses on the social mechanisms through which authority is wielded, and the ways in which the threat of heresy 'can be used for the creation of intragroup solidarity' (Kurtz 1983: 1089). The phrase coge intrare ('compel them to come in') is central to the Church's perspective. It is first found in the Gospel of Luke 14:23: 'Then the master said to the slave, "Go out into the roads and lanes, and compel people to come in, so that my house may be filled."' (Coogan 2010: 1858). Augustine (1887: 642) applied it specifically to heretics in his Writings in Connection with the Donatist Controversy 6:24:

if the power which the Church has received by divine appointment in its due season... be the instrument by which those who are found in the highways and hedges - that is, in heresies and schisms - are compelled to come in, then let them not find fault with being compelled... (trans. J. R. King, and Chester D. Hartranft).

Historically, this approach on the part of the Church led to the Inquisition, which will be considered at section 5, below. Leaving aside such expressions of main force, the Church had other tools at its disposal such as censorship and threats of exclusion including but not limited to excommunication. The existence of comparable forces of 'social control' within the scientific establishment was experienced by the psychologists Eysenck and Nias when they investigated astrology:

many of the people in the scientific establishment would have fitted well into the panel which condemned Galileo! We have become aware of this climate of censorship and intolerance both through reports from individuals directly affected and from remarks warning us that even criticizing astrology in detail, and showing familiarity with its pronouncements, would undermine our scientific standing and reputation. So much for the religion of the open mind (Eysenck and Nias 1982: 220).

From 1559 to 1966 the Church used the Index Librorum Prohibitorum to prevent the circulation of heretical texts. The advent of the internet has meant that other strategies are needed, and given the reach and influence of the internet encyclopaedia Wikipedia in the contemporary West, it might be expected that attempts to exert control could be found here. This has been the experience of Robert Currey - astrologer, entrepreneur and proprietor of 
The Astrology Shop in London: 'I found Wikipedia a very harsh environment for editing "fringe topics"... Sceptical editors seemed to be working together to block any material or paper that might be favourable towards astrology. ${ }^{5}$ Currey suggested that a substantial proportion of these 'sceptical editors' were members of the group 'Guerilla Skeptics'. ${ }^{6}$ As an example of the difficulties he encountered, Currey cited his attempts to correct the account on Wikipedia's 'Astrology and Science' page of a study that was cited as falsifying astrology. This was a piece of research conducted in 1985 by Shawn Carlson which considered astrologers' ability to match astrological charts to personality profiles. As a way of balancing this position, Currey tried to include reference to the 2009 paper by Suitbert Ertel and found that

The anti-astrology editors went to great lengths to suppress the results from Professor Suitbert Ertel's review of the Carlson test as it included results that showed that astrologers were able to match charts with subjects in a blind test to a level that cannot be explained by chance (Currey 2015).

The study by Ertel, a professor of psychology with a background in statistics, concluded that Carlson's study was flawed and this undermined his claim to have provided a strong case against astrology. Further, Ertel found that one of Carlson's studies actually showed astrologers achieving significant levels of success in the test (Carlson 1985: 425; Ertel 2009: 134). Currey reported that the argument used to disallow Ertel's work did not address the substance of that work. Rather, Ertel's article was disallowed because it was published in a journal (Journal of Scientific Exploration) that published articles favourable to astrology and which could not therefore, under Wikipedia rules, be a reliable source. ${ }^{7}$ In effect, therefore, publication of an article in any way supportive of astrology condemns the publishing journal as unreliable. There is here, as Currey noted, a similarity to the no-win structure in witchswimming, wherein a favourable outcome for the victim - not drowning — was proof of their guilt (Davies 1999: 86-100). This is not to suggest that the bulk of astrological practice could be vindicated by scientific tests. The issue here is only to provide an instance of 'social control' being exerted in order to censor astrologers. I will touch on the question of whether astrology is a phenomenon that could be expected to conform to scientific principles in the next section.

\section{The Clarification (and Polarisation) of Beliefs}

Kurtz's fourth characteristic of heresy is that 'The process of defining and labelling heresy has doctrinal as well as social consequences. It is in the heat of escalating conflicts that orthodoxy is formulated, often through explicit disagreement with a position held by "heretics"' (Kurtz 1983: 1090). During conflicts between the orthodox and heretics, positions polarise (Kurtz 1983: 1090). Although this is not an aspect of the process to which Kurtz devotes much attention, the polarisation of positions often includes the stereotyping and even caricaturing of each side by the other. Jerry B. Pierce gives an account of such a process in his work on the medieval Order of Apostles:

inquisitors and other ecclesiastical authorities essentially employed a template of 'typical' heretical depravities, including sexual licentiousness and aberrations, general

\footnotetext{
${ }^{5}$ Email communication with Robert Currey 10 January 2015, reproduced with permission.

${ }^{6}$ Currey has written a full account of his experience of 'guerilla skepticism' at Currey 2014. A critique of guerilla skepticism written by a skeptic can be found in O’Neill 2014A and 2014B.

${ }^{7}$ The relevant Wikipedia rules are at: http://en.wikipedia.org/wiki/Wikipedia:Fringe_theories, January 2016.
} 
immorality, seditious behavior, and, perhaps most importantly, a direct affiliation with the Devil. Taken together, these traits were made to appear to necessitate the removal of these so-called traitors to divine order and prevailing systems of justice by any means and at all costs (Pierce 2012: 3-4).

Contemporary critics such as Dawkins often attribute traits to astrologers that sit more easily with a materialist worldview than 'affiliation with the Devil', but entail a more or less equal level of wickedness. Thus astrologers are seen as fraudulent, as seen in section 1 . They are quite often assumed to have huge incomes, on the basis, as Campion notes, of little or no evidence (Campion 2012B: 4-5). They are also often characterised as exerting total, and harmful, control over their readers and clients. Dawkins, for instance, contends that under the influence of astrology, people seeking relationships errantly discard eleven twelfths of all potential partners (Dawkins 1995: 18). The assumption here seems to be that astrologers typically tell people to disregard all potential partners except those at whose birth the Sun was in a particular sign - a claim for which Dawkins offers no evidence. The primary relevance of Dawkins' assertion here, though, is that it is one example amongst many of astrologers being portrayed as exerting a malign influence. It is therefore similar to the charge levelled against astrologers by Augustine - that they are in league with evil spirits, "whose concern is to instil and confirm in men's minds those false and baneful notions about "astral destiny"' (Augustine, City of God: V.7, 1984: 188).

I would like to dwell on Kurtz's observation that 'positions polarize' during conflict between the orthodox and 'heretics', and suggest that it is commonly the case that the beliefs of the latter group are misrepresented so as to better fulfil the function that heresiology performs for orthodoxy: defining what orthodoxy is not. This can be seen, in a situation where scientism is the orthodoxy and religion the heresy, in Dawkins' complaint: 'We were to debate against a trio of, as it turned out, rather halfhearted religious apologists ("Of course I don't believe in a God with a long white beard, but . ..”')' (Dawkins 2007). Where religion is concerned, secular fundamentalism's battle of choice is against simplistic notions of an anthropomorphic God (Armstrong 2010: 289-96). Similarly, when astrology is attacked the battle often features a simplistic account of astrological work with little or no acknowledgement of the degrees of complexity and plurality of belief of actual astrologers. Thus for example when Dawkins' article 'The Real Romance in the Stars' was reprinted in the UK Astrological Association's Journal, he acknowledged that a joke about all Scorpios being run over by egg lorries on the same day was 'a joke against "naïve sun sign” astrology which is shunned by other astrologers' (Dawkins 1996: 141). But when he subsequently wrote Unweaving the Rainbow, he saw it as acceptable to reiterate the simplistic version, writing of 'the facile and potentially damaging way in which astrologers divide humans into 12 categories’ (Dawkins 1998: 115).

The characterisation of astrology as a science, which is assumed by many critiques of the subject, is itself a simplification. In Campion's surveys at astrological conferences between 1999-2011, the percentage of astrologers who characterised it as science was as low as $24.5 \%$ in one instance, while those who saw it as a form of divination was as high as 72.9\% (Campion 2012B: 178). To characterise astrology as divination is to put it on a similar footing to systems of divination such as the I Ching or tarot cards — to eschew, therefore, the idea of scientifically measurable influences. As was seen above, this is essentially the position taken by Origen. The crucial nature of this characterisation can be seen in a brief conversation between the astrologer Geoffrey Cornelius and Paul Kurtz, co-editor of Objections to Astrology. Cornelius raised the possibility that astrology might be considered to function purely on a poetic level; Paul Kurtz said that if that were the case, there would be no problem with astrology (Cornelius 1998). This supports the possibility that emerged in 
section 1, that many of the attacks directed towards astrology are based on a perception of astrologers as scientific insiders. Such claims are made by some astrologers, although they may sometimes be a function of the polarisation of views that is the theme of this section. Thus in her thesis, grounded in ethnographic research among contemporary astrologers in the UK, Alie Bird observed that 'many astrologers, if cornered by persistent sceptics at parties, will invoke science as an uncertain ally rather than admit to the divinatory nature of their practice' (Bird 2006: 104). In characterising a divinatory perspective on astrology, Cornelius argued that such claims are largely misguided:

It is disingenuous of astrologers to even hint at a scientific basis of the sort understood in physics or biology. We'd be on so much stronger ground if we said, 'What we do is a type of symbolic imagination. We believe it has real effect and real results. This is something you psychologists and parapsychologists ought to take a look at. What we do is actually about remarkable powers of human imagination that imply something very extraordinary about the nature of reality and the nature of mind' (Cornelius 1998).

Questions regarding the appropriate domain of astrology such as those raised by Cornelius have long been an issue. In the second half of the thirteenth century, Aquinas effected a degree of accommodation between the Church and astrology by arguing:

acts of choice and movements of the will are controlled immediately by God. And human intellectual knowledge is ordered by God through the mediation of the angels. Whereas matters pertinent to bodily things, whether they are internal or external, when they come within the use of man, are governed by God by means of the angels and the celestial bodies.' (Thomas Aquinas, Summa Contra Gentiles, 3.91.2 trans. Vernon J. Bourke 1990 [1956]:40).

In the analysis of Aquinas, it was not heresy to apply astrology to the material world. This has been reversed by some of astrology's contemporary scientific critics. For them, the material world is the exclusive domain of science and therefore astrology is heretical precisely to the extent that it claims purchase on materiality. An example is Paul Kurtz's willingness to tolerate an astrology that works in a similar way to poetry but finds no footing in the world of material science. A similar position, based on a dichotomy between what they term 'subjective astrology' and 'objective astrology', is taken by Dean, Ertel, Kelly, Mather, and Smit, a group of astrology's most eminent critics (Phillipson 2000: 128-30). There is almost a basis for rapprochement between some astrologers and critics of astrology here, stymied only if the astrologers insist that astrology has 'real effect and real results' (Cornelius 1998).

\section{Inquisition}

Kurtz's fifth characteristic of heresy is that 'the process of defining and denouncing heresy and heretics is a ritual' and that in the case of Christianity, these rituals 'reached their apotheosis with the formation of the Inquisition and the use of the Augustinian formula coge intrare, which gave infidels and heretics two choices: conversion and submission or extirpation' (Kurtz 1983: 1090, 1091). In the interests of brevity I prefer to side-step the term 'ritual', since the term is open to such a range of interpretations (Leach 1968: 526). It seems more straightforwardly explanatory to take 'inquisition' as the title for this section.

Jacques Berlinerblau summarises this facet of the treatment of heretics by saying that in it, the prevalent orthodoxy 'institutionally manages deviant individuals and groups through 
coercive mechanisms (e.g, physical and symbolic violence, excessive taxation, ostracism, etc.) or through “re-education”, compromise, accommodation and so on' (Berlinerblau 2001: 340). For the Church, authority for violence and execution was provided by Aquinas who, in his Summa Theologica Part 2.2, Question 11 Article 3, a passage that helped shape the Inquisition, wrote of the heretic:

If he is yet stubborn, the Church no longer hoping for his conversion, looks to the salvation of others, by excommunicating him and separating him from the Church, and furthermore delivers him to the secular tribunal to be exterminated thereby from the world by death. (trans. The Fathers of the English Dominican Province, 1922: 160 $-1)$.

It would be egregious to imply that the travails of contemporary astrologers, or other targets for secular fundamentalism, are similar in extent to the sufferings of the Inquisition's victims. That said, I want to suggest that there are 'coercive mechanisms' against astrologers that can be seen to be similar in principle.

In 2011 the professor of physics Brian Cox and comedian/science presenter Dara Ó Briain repeatedly described astrology as 'rubbish' on the BBC programme 'Stargazing Live'. The UK's Astrological Association (AA) instigated an online petition in protest. ${ }^{8}$ Ó Briain encouraged his Twitter followers to submit bogus signatures to this petition, effectively sabotaging it. Frances Clynes, a lecturer in computing who was on the AA's council at the time and involved in organising the petition, then found that some followers of Ó Briain had traced her email address and were emailing her directly. Concerning these emails she told me:

Most of them contained the usual accusations that we are becoming millionaires by exploiting the vulnerable, and words like 'fraud' were used. A small number of them contained threats. One of them said, 'Don't go down any dark alleys anytime soon'. Several said things like 'you're dead', or in fact 'your dead'. Many of them were grammatically incorrect. The most frightening was the one that said, 'I know where you live'. That too could easily be found if they wanted to. Writing this now four years later, it still feels threatening. ${ }^{9}$

I note the escalation in this sequence of events. First astrology was treated dismissively, from a position of implicit authority and orthodoxy. Then it was deemed acceptable and even humorous to deny the astrologers a voice by sabotaging their petition - which could be considered symbolic violence. Further, it seemed acceptable to a few to threaten astrologers with violence and death, in the name of science and rationality.

A salient question is whether this episode was an aberration, an isolated irruption of shadowy psychological issues on the part of a few, or whether it embodies an attitude found in the rhetoric of many secular fundamentalists. The argument for the latter possibility might include Dawkins's suggestion, cited earlier, that astrologers should be jailed; and his statement, 'I am talking about fighting it [astrology] seriously instead of humouring it as a piece of harmless fun' (Dawkins 1995: 17). The language of armed struggle is frequently found in secular fundamentalism: at the end of 2013 a letter from D. J. Grothe, President of the 'James Randi Educational Foundation' asked, 'Will you join the battle against unreason?'

\footnotetext{
${ }^{8}$ The episode is discussed at: Campion 2012: 106-7;

http://www.astrologicalassociation.com/pages/bbc/petition.pdf, accessed January 2014.

${ }^{9}$ Email communication with Frances Clynes, 15 February 2015, reproduced with permission.
} 
and invited donations which would be used for this cause, including support of the 'guerilla skeptics' (Grothe 2013). Dawkins, recounting a public discussion on religion in which he, A.C. Grayling and Christopher Hitchens faced a group of religious believers, cited with approval Grayling's remark before the discussion that 'Hitch will spray AK47 ammo at the enemy in characteristic style' (Dawkins 2007). The only thing he seemed to find worrying about the analogy is that the word 'spray' 'underestimates the deadly accuracy of his [Hitchens’s] marksmanship’ (Dawkins 2007). Tina Beattie, who cites this episode, refers to 'the testosterone-charged nature of this debate' - a charge she levels at both sides — and it seems difficult to disagree with that observation (Beattie 2007: 4, 10). Oestmann, Rutkin and von Stuckrad have argued,

the question of astrology's ontological status reveals a strategy of 'othering'... [characterised by an attitude that framed] the debate polemically in terms of (e.g.) 'science' vs. 'pseudo-science' and 'rationality' vs. 'superstition'. These terms... reflect the socio-professional identities and conceptual perspectives of 'modern' people who view themselves as progressive, rational and enlightened, against which the 'other' was constructed as a necessary counterpart (Oestmann, et.al. 2005: 2-3).

As the 'other', astrologers are effectively characterised as 'primitive' with all the pejorative freight the term carries, so that the critic of astrology's duty would conform to Edward B. Tylor's prescription for the dutiful ethnographer: 'to expose the remains of crude old cultures which have passed into harmful superstition, and to mark these out for destruction... for the good of mankind' (Tylor 1920: 26). Darwinian evolution may have replaced the laws of God, but heretics — it seems — still must be sought out and punished.

\section{Conclusion}

The application of Kurtz's five-fold anatomy of heresy to contemporary secular criticisms of astrology has shown significant parallels to the treatment of heresy by the Church. First, astrologers are seen as 'deviant insiders' who are assumed to practise astrology as if it were a science, whilst knowing that it cannot be. Second, astrology is seen as a threat to the authority of science with the potential to lead people away from the orthodoxy of science. Third, the views and arguments of astrologers are suppressed by groups who believe that they need to protect science, to establish or preserve its status as the prevalent orthodoxy. Fourth, when it is criticised, astrology is often taken to be exhaustively defined when considered as erroneous, discredited science. This identification of astrology as 'what science is not' is simplistic, driven more by a need to reify science as an orthodox belief-system than by genuine enquiry. Finally, astrologers are subjected to 'othering'; there is an incipient spirit of inquisition amongst some critics which is prepared to silence the astrologers by force if necessary.

In the preceding discussion, the treatment of astrology has shed light on scientism. What has emerged is that the treatment of astrologers by scientism is closely analogous to the treatment of heretics by the Church with, in each case, an orthodoxy to be defended. Aside from the inherent value in disclosing and investigating prejudice, particularly when it is associated with threats and coercion, I see two issues emerging from this research. The first is that there can be contradiction between the ideals typically associated with science - the 'religion of the open mind' as Eysenck and Nias put it (Eysenck and Nias 1982: 220) and the positions taken by some of science's would-be guardians. The second major issue to emerge is that there is evidence here of the extent to which scientism has become the de facto orthodox belief system of the West. This has been exemplified in this paper through analysis of the way in which the perception of astrology as irrational belief evokes atavistic responses 
which mirror those seen in the persecution of heretics by the Church. There is an ironic symmetry here which suggests that the more belief changes, the more it stays the same.

\section{References}

Adorno, Theodor. 1994 [1974]. The Stars Down to Earth (London: Routledge)

Aldridge, Robert E. 1999. 'The Lost Ending of the Didache' Vigilae Christianae, 53.1: 1-15.

Aquinas, Thomas. 1922. Summa Theologica Part 2.2 in The 'Summa Theologica' of St Thomas Aquinas, Part II, Second Part, trans. The Fathers of the English Dominican Province (London: Burns, Oates and Washbourne).

Armstrong, Karen. 2010. The Case for God: What Religion Really Means (London: Vintage).

Augustine, Saint. 1984. Concerning the City of God against the Pagans, trans. Henry Bettenson (London: Penguin)

Augustine, Saint, 1873. Lectures or Tractates On The Gospel of John in The Works of Aurelius Augustine, Bishop of Hippo - A New Translation Vol. X, trans. Marcus Dods (Edinburgh: T. \& T. Clark).

Augustine, Saint, and J. R. King, and Chester D. Hartranft (trans). 1887. Writings in Connection with the Donatist Controversy in Nicene and Post-Nicene Fathers First Series, Volume IV - St Augustine: The Writings Against the Manichaeans, and Against the Donatists, Philip Schaff (ed.), (New York: Christian Literature Publishing).

Augustine, Saint, and R. Teske (trans). 1995. Arianism and Other Heresies in The Works of Saint Augustine, A Translation for the $21^{\text {st }}$ Century Vol. 18 (New York: Hyde Park).

Beattie, Tina. 2007. The New Atheists: The Twilight of Religion and the War on Religion (London: Darton, Longman and Todd).

Berlinerblau, Jacques. 2001. 'Towards a Sociology of Heresy, Orthodoxy, and Doxa', History of Religions 40.4:327-351.

Bird, Alison Gwendy. 2006. Astrology in Education: An Ethnography (Ph.D. thesis: University of Sussex).

Bok, Bart J., Jerome, Lawrence E. 1975. 'Objections to Astrology' (introductory remarks) in Bok, Bart J., Jerome, Lawrence E., Kurtz, Paul. 1975. Objections to Astrology - A Statement by 192 Leading Scientists (Buffalo, NY: Prometheus): 10.

Campion, Nicholas. 2008. The Dawn of Astrology. A Cultural History of Western Astrology. Volume 1: The Ancient and Classical Worlds (London: Continuum).

Campion, Nicholas. 2012A. Astrology and Cosmology in the World's Religions (New York University Press). 
Campion, Nicholas. 2012B. Astrology and Popular Religion in the Modern West - Prophecy, Cosmology and the New Age Movement (Farnham: Ashgate).

Carlson, Shawn. 1985. 'A double blind test of astrology’ Nature 318: 419-425.

Cassidy, Laurence L. 1994. 'The Believing Christian as a Dedicated Astrologer' in Astrology Quarterly Vol. 64 No. 3.

Chapman, Geoffrey (trans.). 1999. Catechism of the Catholic Church (Revised Edition) (London: Burns \& Oates).

Conkle, Daniel O. 1995. 'Secular Fundamentalism, Religious Fundamentalism, and the Search for Truth in Contemporary America’, Journal of Law and Religion XII.2: 337-370.

Coogan, Michael D. 2010. The New Oxford Annotated Bible (Fully Revised Fourth edn.) (Oxford University Press).

Cooper, Michael T. 2007. 'New Testament Astral Portents: God's Self-Disclosure in the Heavens’, Journal for the Study of Religion, Nature and Culture 1.2 189-209.

Cornelius, Geoffrey. 1998. 'Is Astrology Divination and Does it Matter?' at www.cosmocritic.com/pdfs/Cornelius_Geoffrey_Is_Astrology_Divination.pdf. Originally published in The Mountain Astrologer 81 (Oct-Nov 1998).

Cross, F. L. \& Livingstone, E. A. 1997. 'Heresy’ in Cross, F. L. \& Livingstone, E. A. (eds.) The Oxford Dictionary of the Catholic Church (3rd edn.): 758-9.

Cumont, Franz. 1912. Astrology and Religion Among the Greeks and Romans (New York: G. P. Putnam's Sons).

Currey, Robert. 2014. 'Wikipedia has been hijacked by "guerilla skeptics”! An Idealistic Project is infected with systemic bias, at http://www.astrologer.com/tests/wp.htm_.

Curry, Patrick in: Willis, Roy, and Curry, Patrick. 2004. Astrology, Science and CulturePulling Down the Moon (Oxford: Berg).

Davies, Owen. 1999. Witchcraft, Magic and Culture: 1736-1951 (Manchester University Press).

Dawkins, Richard. 1995. 'The real romance in the stars', Independent on Sunday 31 December 17-18, at: https://www.independent.co.uk/voices/the-real-romance-in-the-stars1527970.html

Dawkins, Richard. 1996. 'The Real Romance of the Stars’ The Astrological Journal (38.3) 135-141.

Dawkins, Richard. 1998. Unweaving the Rainbow (London: Allen Lane).

Dawkins, Richard. 2007. 'Bible Belter', The Times Literary Supplement, 5 September 2007, at http://www.the-tls.co.uk/tls/public/article759882.ece 
Doe, Norman. 2013. Christian Law: Contemporary Principles (Cambridge University Press).

Ehrman, Bart D. (ed. \& trans.). 2003. The Apostolic Fathers, Volume I (Cambridge Mass: Loeb/Harvard University Press).

Ertel, Suitbert. 2009. ‘Appraisal of Shawn Carlson's Renowned Astrology Tests', Journal of Scientific Exploration 23.2:125-137.

Eysenck, H. J. and Nias, D. K. B. 1982. Astrology: Science or Superstition? (London: Maurice Temple Smith).

Feyerabend, Paul. 1999. Knowledge, Science and Relativism - Philosophical Papers Volume 3 (Cambridge: Cambridge University Press).

Feyerabend, Paul. 1978. Science in a Free Society (London: NLB).

Feyerabend, Paul K. 1975. 'How to Defend Society Against Science', Radical Philosophy 11:3-8.

Fuller, Steve. 2007. Science vs Religion? Intelligent Design and the Problem of Evolution (Cambridge: Polity).

Grayling, A.C. 2006. 'Apparently it's Emetic' in 'Letters', London Review of Books, Vol. 28.21, 2 November 2006, at http://www.lrb.co.uk/v28/n21/letters.html

Grothe, D. J. 2013. 'Will you join the battle against unreason?' at http://archive.randi.org/site/index.php/jref-news/2294-will-you-join-the-battle-againstunreason.html

Hammer, Olav and Kocku von Stuckrad. 2007. 'Introduction: Western Esotericism and Polemics’ in Olav Hammer \& Kocku von Stuckrad (eds.), Polemical Encounters - Esoteric Discourse and its Others (Leiden: E.J. Brill).

Hegedus, Tim. 2007. Early Christianity and Ancient Astrology (Patristic Studies Vol. 6) (New York: Peter Lang).

Irenaeus, Saint, and Dominic J. Unger and John J. Dillon (trans). 1992. St. Irenaeus of Lyons Against the Heresies Volume 1 Book 1 (New York, N.Y.: Newman Press).

Jerome, and Philip Schaff \& Rev. Henry Wallace (eds.) 2007 [1893]. Nicene and Post-Nicene Fathers, Second Series: Volume VI - Jerome: Letters and Select Works (New York: Cosimo).

Kim, Young Richard. 2015. 'The Transformation of Heresiology in the Panarion of Epiphanus of Cyprus' in Geoffrey Greatrex, Hugh Elton, Lucas McMahon (eds.), Shifting Genres in Late Antiquity (Farnham: Ashgate): 53 - 68.

Kurtz, Lester R. 1983. 'The Politics of Heresy’, American Journal of Sociology 88.6: 10851115. 
Leach, Edmund R. 1968. 'Ritual' in Sills, D. (ed.) International Encyclopaedia of the Social Sciences Vol. 13 (New York: Macmillan, 1968): 520-6.

Mühlenberg, Ekkehard. 2001. 'Heresies and Schisms' in David B. Barrett, Erwin Fahlbusch, Jan Milič Lochman, John Mbiti, Jaroslav Pelikan, Lukas Vischer (eds.), Geoffrey W.

Bromiley (trans. and ed.). 2001. The Encyclopaedia of Christianity Vol. 2 (Grand Rapids MI/Leiden: William B. Eerdmans/E.J. Brill).

O’Neill, Rebecca. 2014A. ‘Guerilla Skepticism on Wikpedia Project - a Discussion', at http://skepticireland.com/archives/1063

O’Neill, Rebecca. 2014B. 'A Critique of Guerilla Skepticism on Wikipedia (GSoW) - Part 2’, at http://skepchick.org/2014/08/guest-post-a-critique-of-guerrilla-skepticism-onwikipedia-gsow-part-2/

Oestmann, Günther, H. Darrel Rutkin, Kocku von Stuckrad. 2005. 'Introduction: Horoscopes and History' in Oestmann, Günther, H. Darrel Rutkin, Kocku von Stuckrad, Horoscopes and Public Spheres: Essays on the History of Astrology (Berlin: Walter de Gruyter).

Origen, and George Lewis (trans.). 1911. The Philocalia of Origen (Edinburgh: T. \& T. Clark).

Phillipson, Garry. 2000. Astrology in the Year Zero (London: Flare).

Pierce, Jerry B. 2012. Poverty, Heresy and the Apocalypse: The Order of Apostles and Social Change in Medieval Italy 126 -1307 (London: Bloomsbury Academic).

Polanyi, Michael. 1962. Personal Knowledge: Towards a Post-Critical Philosophy (corrected edition) (London: Routledge).

Popper, Karl. 1969. Conjectures and Refutations: The Growth of Scientific Knowledge (3rd edn.) (London: Routledge \& Kegan Paul).

Royalty, Robert M. 2013. The Origin of Heresy: A History of Discourse in Second Temple Judaism and Early Christianity (New York: Routledge).

Russell, Jeffrey Burton. 1992. Dissent and Order in the Middle Ages: The Search for Legitimate Authority (Eugene, OR: Wipf and Stock).

Sagan, Carl. 1976. 'Readers' Forum' in The Humanist, Vol. 36.1:2 (Reprinted in: Sagan, Carl. 1995. The Demon-Haunted World: Science as a Candle in the Dark [New York: Random House] 285.)

Tertullian, and J. H. Waszink, J. C. M. van Winden and P. G. van der Nat (trans). 1987. Tertullianus, De Idololatria - Critical Text, Translation and Commentary) (Leiden: E. J. Brill, 1987).

Tylor, Edward B. 1920. Primitive Culture: Researches into the Development of Mythology, Philosophy, Religion, Language, Art, and Custom, Vol. 1 (London: John Murray). 
Versluis, Arthur. 2006. The New Inquisitions: Heretic-Hunting and the Intellectual Origins of Modern Totalitarianism (Oxford University Press).

Williams, Richard N. and Robinson, Daniel N. (eds.). 2015. The New Orthodoxy (London: Bloomsbury Academic). 